\title{
The Role of the Population, Family Planning and Family Development Program (KKBPK) in Reducing Stunting Prevalence
}

\author{
Peran Program Kependudukan, Keluarga Berencana, dan \\ Pembangunan Keluarga (KKBPK) dalam Menurunkan \\ Prevalensi Stunting
}

\author{
Agus Mauluddin ${ }^{1}$, Novianti ${ }^{2}$ \\ 1Fakultas Ilmu Sosial dan Ilmu Politik, Universitas Indonesia \\ Email: agusmauluddin@sociologist.com \\ 2Puslitbang Upaya Kesehatan Masyarakat, Badan Litbangkes \\ Email: novianti.ms@gmail.com
}

\begin{abstract}
Stunting is a common issue in the global network. Stunting is one of the fundamental problems that hinder the development of toddlers in the world today and has received great international attention, at least in the last decade. In 2017, for example, around 150.8 million (22.2\%) children in the world were stunted. The stunting prevalence data collected by WHO (2005-2017) puts Indonesia in third position, the country with the highest prevalence in the Southeast Asia region (36.4\%). Basic health research data in 2018 shows the prevalence of stunting in Indonesia is around $30.8 \%$ and is still below the world standard (WHO), which is a maximum of 20\%. Many interventions have been carried out to reduce the prevalence of stunting, especially from a (specific) health aspect. However, interventions that only target specific interventions are still ineffective, hence the need for interventions that involve various sectors or stakeholders. The argument from this study is the need for stunting prevention interventions that involve multisectors, not only specific ones (health), but also sensitive interventions (Population, Family Planning, and Family Development programs). Strengthened by the latest research shows the focus of studies on multi-sector stunting prevention. Recent studies also prove that it is important to pay attention to a family-based approach (family development) in the prevention of stunting, especially in regards to birth interval management which has an effect on reducing the prevalence of stunting.
\end{abstract}

Keywords: stunting, family development, birth interval, program KKBPK

\begin{abstract}
ABSTRAK
Kejadian stunting (kerdil) merupakan isu bersama dalam jaringan global. Stunting menjadi salah satu permasalahan mendasar yang melintangi perkembangan balita di dunia saat ini dan mendapatkan atensi besar dunia internasional, sekurangnya dalam satu dekade terakhir. Di tahun 2017, misalnya, sekitar 150,8 juta (22,2\%) anak di dunia mengalami stunting. Data prevalensi stunting yang dikumpulkan WHO (2005-2017) menempatkan Indonesia di posisi ketiga, negara dengan prevalensi tertinggi di wilayah Asia Tenggara (36,4\%). Data riset kesehatan dasar tahun 2018 menunjukkan prevalensi stunting di Indonesia berkisar di angka 30,8\% dan masih di bawah standar dunia (WHO) yaitu maksimal 20\%. Banyak intervensi yang sudah dilakukan untuk menurunkan prevalensi stunting, utamanya dari aspek kesehatan (spesifik). Namun, intervensi yang dilakukan dengan hanya menyasar intervensi spesifik
\end{abstract}


masih kurang efektif, maka perlunya intervensi yang melibatkan berbagai sektor atau stakeholder. Argumen dari kajian ini perlunya intervensi pencegahan stunting yang melibatkan multi-sektor, tidak hanya yang sifatnya spesifik (kesehatan), tetapi juga intervensi sensitif (program Kependudukan, Keluarga Berencana, dan Pembangunan Keluarga). Diperkuat dengan riset-riset terbaru memperlihatkan fokus kajian pada multi-sektor pencegahan stunting. Penelitian-penelitian terbaru juga membuktikan bahwa penting memperhatikan pendekatan berbasis keluarga (pembangunan keluarga) di dalam pencegahan stunting, terutama terkait pengaturan interval kelahiran yang berpengaruh terhadap penurunan prevalensi stunting.

Kata Kunci: Stunting, Pembangunan Keluarga, Interval Kelahiran, Program KKBPK

\section{PENDAHULUAN}

Masalah stunting (kerdil) merupakan isu bersama dalam jaringan global. Stunting menjadi salah satu permasalahan genting (urgen) yang melintangi perkembangan balita di dunia saat ini dan mendapatkan atensi besar dunia internasional, sekurangnya dalam satu dekade terakhir. Di tahun 2017, misalnya, sebanyak 22,2\% atau sekitar 150,8 juta anak (balita) di dunia mengalami stunting. Proporsi terbesar prevalensi stunting global (lebih dari setengah balita stunting di dunia) berada di negara-negara Asia yaitu sebesar 55\%, sedangkan lebih dari sepertiganya, yaitu 39\% berada di kawasan negara di Afrika. Dari 83,6 juta balita stunting di Asia, proporsi terbesar berada di Asia Selatan, berkisar antara 58,7\% dan proporsi terkecil di Asia Tengah dengan persentase 0,9\% (Joint Child Malnutrition Eltimates, 2018; Pusat Data dan Informasi Kemenkes RI, 2018).

Data prevalensi stunting yang dikumpulkan World Health Organization (dalam Kemenkes, 2018), Indonesia termasuk ke dalam negara ketiga dengan prevalensi tertinggi di wilayah Asia Tenggara/South-East Asia Regional (SEAR) yaitu rata-rata prevalensi stunting (tahun 20052017) sebesar $36,4 \%$, dengan Timor Leste $(50,2 \%)$ di urutan pertama, sedangkan terendah adalah Thailand $(10,5 \%)$. Prevalensi balita sangat pendek kategori stunting dan pendek, usia 0-59 bulan di Indonesia tahun 2017 adalah 9,8\% dan 19,8\%. Provinsi dengan prevalensi tertinggi balita sangat pendek dan pendek pada usia 0-59 bulan tahun 2017 adalah Nusa Tenggara Timur, sedangkan provinsi dengan prevalensi terendah adalah Bali (Riskesdas, 2018; PSG, 2017). Begitu juga data terbaru hasil riset kesehatan dasar (Riskesdas) tahun 2018 menunjukkan provinsi dengan prevalensi stunting tertinggi adalah Nusa Tenggara Timur $(42,6 \%)$ dan DKI Jakarta $(17,7 \%)$ yang terendah. Masih dalam hasil riskesdas tahun 2018, dengan indikator yang berbeda tetapi memiliki determinan terjadinya stunting, proporsi panjang badan lahir $<48 \mathrm{~cm}$ pada anak umur 0-59 bulan menurut provinsi, tahun 2013-2018 Bali tetap menjadi provinsi terendah (sama dengan hasil PSG 2017), sedangkan --terdapat perbedaan dengan data Pemantauan Status Gizi (PSG) tahun 2017 dengan hasil Riskesdas 2018- provinsi tertinggi prevalensinya dari NTT ke Gorontalo, tetapi memiliki kesamaan yaitu berada di wilayah timur Indonesia. Perbandingan menarik lainnya, dapat dilihat dari disparitas sosio-spasial desa kota. Data riskesdas 2018 menunjukkan prevalensi tertinggi berada di perdesaan dibandingkan dengan perkotaan (Kementerian Kesehatan RI Badan Penelitian dan Pengembangan, 2018; Kementerian Kesehatan RI, 2017; Mauluddin, 2019).

Permasalahan stunting ini menjadi masalah mendasar pada 1000 Hari Pertama Kehidupan (HPK). Pada 1000 HPK --antara 9 bulan mengandung dan 2 tahun menyusui-- adalah masamasa kritis untuk pertumbuhan dan perkembangan. Periode ini merupakan fondasi untuk menentukan "masa depan" anak, dan menjadi sebuah kampanye gerakan global dewasa kini (thousanddays.org, 2019 -diakses pada 10 Desember 2019).

Munculnya masalah stunting ini akan berakibat pada tumbuh kembang anak dan berdampak pada memperlambat kemajuan generasi bangsa kini dan mendatang. Dalam definisinya stunting merupakan masalah gizi kronis pada balita yang ditandai dengan tinggi badan yang lebih pendek dibandingkan dengan anak seusianya. Kondisi ini diukur dengan panjang atau tinggi badan yang lebih dari minus dua standar deviasi median standar 
pertumbuhan anak (<-2SD) dari WHO (Pusat Data dan Informasi Kemenkes RI, 2018).

Mencermati permasalahan yang dipaparkan di atas, banyak intervensi yang sudah dilakukan untuk menurunkan prevalensi stunting, utamanya dari aspek kesehatan (lih Riskesdas, 2018). Namun, intervensi yang dilakukan dengan hanya menyasar intervensi spesifik masih kurang efektif, maka perlunya intervensi yang melibatkan berbagai sektor atau stakeholder.

Argumen dari artikel ini yaitu perlunya intervensi pencegahan stunting yang melibatkan multi-sektor, tidak hanya yang sifatnya spesifik (kesehatan), tetapi intervensi sensitif (misalnya program KKBPK - diperdalam di pembahasan dalam artikel ini, kenapa menjadi penting). Sekurangnya satu dekade terakhir, riset terbaru memiliki fokus pada integrasi intervensi spesifik (kesehatan/nutrisi) dan intervensi sensitif (keluarga berencana). Misalnya saja lembaga internasional, seperti WHO dan USAID, memiliki prioritas pada pengintegrasian kedua intervensi itu (Allison, 2010 dalam Rana dan Goli, 2017). Diperkuat dengan studi Rana dan Goli (2017) yang menjelaskan strategi optimalisasi sinergi antara nutrisi ibu \& anak dan keluarga berencana.

Penelitian-penelitian terdahulu membuktikan melalui temuannya bahwa pentingnya memperhatikan pendekatan berbasis keluarga (pembangunan keluarga) -di samping intervensi spesifik-- di dalam pencegahan stunting, terutama terkait pengaturan interval kelahiran yang berpengaruh terhadap penurunan prevalensi stunting (misalnya lih Rana et al., 2019; Takele et al., 2019; Rana dan Goli, 2018; Rana dan Goli, 2017; Sobrino et al., 2017; Danaei et al., 2016; Saxton et al., 2016; Rahman et al., 2016; Rostein, 2005).

\section{METODE PENELITIAN}

Penelitian ini menggunakan pendekatan kualitatif studi literatur. Berbagai sumber rujukan dari artikel jurnal internasional dan nasional dikumpulkan dan direduksi sesuai relevansi kajian. Artikel terpilih selanjutnya masuk pada tahap review (matriks analisis) dan mengerucut kepada telaah topik spesifik yaitu terkait stunting, masalah kependudukan, keluarga berencana, dan pembangunan keluarga. Pengkajian yang sudah dilakukan kemudian disajikan, diberikan konteks, dan diperkuat dengan data-data pendukung, seperti data BPS, WHO, Kemenkes, dan BKKBN.

\section{HASIL DAN PEMBAHASAN}

\section{Permasalahan Stunting di Indonesia dan Global}

Kejadian stunting menjadi permasalahan di dunia dewasa kini, begitu juga dengan Indonesia. Pemerintah Indonesia sangat konsen pada isu ini dan berupaya melakukan berbagai intervensi dalam menanggulangi stunting. Di periode pertama pemerintahan Presiden Joko Widodo (2014-2019), misalnya, pencegahan stunting masuk ke dalam pembangunan prioritas, atau kerap disebut dengan Nawacita, terutama pada Nawacita ke-5. Khususnya pada Nawacita tahun ke-4 pembangunan manusia (BKKBN, 2018). Di awal pemerintahan keduanya, konsen pada pencegahan stunting tidak berubah, bahkan lebih diperkuat, karena fokus di periode kedua memang pada pembangunan Sumber Daya Manusia (SDM) Indonesia. Satu di antaranya langkah membangun SDM Indonesia unggul yaitu dengan mengentaskan stunting.

Pada saat pidato politik Presiden Joko Widodo pertama kali setelah diumumkan melanjutkan ke periode keduanya, stunting menjadi masalah yang mendapatkan perhatian penting. "Jangan sampai ada Stunting." ucap Presiden saat pidato politik pertamanya (KSP, 2019). Memang dari data yang sudah dihasilkan persentase minimal prevalensi stunting menurut standard dunia (lih data WHO) yaitu di angka 20\%. Indonesia saja jika merujuk data riskesdas 2018, misalnya, mengalami penurunan, walaupun angka rata-ratanya belum sesuai atau mendekati angka maksimal 20\% dari WHO. Data riskesdas (2018) menunjukkan terdapat penurunan prevalensi stunting dari hasil riskesdas tahun 2013 sebesar 37,2\% menjadi 30,8\% di tahun 2018. Nusa Tenggara Timur menjadi provinsi dengan prevalensi stunting tertinggi di Indonesia, dengan persentase $42,6 \%$ dan DKI Jakarta $(17,7 \%)$ yang terendah.

Sebagai perbandingan riset-riset yang sudah dilakukan para peneliti dunia dapat menjadi gambaran, kejadian stunting dan temuan-temuan riset yang menarik di belahan dunia dalam 
satu dekade terakhir. Mengenai kasus stunting yang diderita anak usia 6 hingga 59 bulan di Ethiopia, misalnya, disebabkan karena praktik minum dari sumber air yang tidak aman untuk kesehatan. Selain itu karena jarang mengkonsumsi makanan yang bersumber dari hewan (sumber hewani), seperti daging, telur, susu, dan lain-lain. Kemudian, terlambat memberikan ASI sesaat setelah kelahiran anak (IMD), serta kurangnya pemberian vaksin (Batiro et al., 2017).

Stunting merupakan penanda risiko buruk pada perkembangan seorang anak pada usia tersebut. Data global, misalnya, menyebutkan pada tahun 2017, sekitar 155 juta anak di bawah 5 tahun (balita) diperkirakan mengalami stunting (kerdil). Usia 6 sampai 59 bulan merupakan waktu prioritas untuk melakukan intervensi dan desain rencana mengurangi prevalensi stunting di akar rumput (Batiro et al., 2017).

Fenomena stunting pada umumnya menyerang anak-anak di bawah usia lima tahun (6 hingga 59 bulan). Seperti penelitian Danaei et al., (2016) di 137 negara berkembang, memperkirakan usia rentannya adalah dari 24-35 bulan (akhir periode kerentanan 1000 HPK). Sanitasi yang buruk merupakan faktor utama kedua terjadinya stunting secara global dan di Asia Selatan, Afrika sub-Sahara, dan Asia Timur dan Pasifik setelah kelahiran prematur (37 minggu kelahiran) terjadinya stunting di negara-negara berkembang. Sedangkan faktor risiko terkait dengan masalah gizi anak dan infeksi adalah faktor risiko utama kedua di wilayah lain (Danaei et al., 2016). Hal demikian menjadi catatan pentingnya intervensi sensitif dan spesifik pencegahan stunting.

Hal lain yang perlu dilakukan secara ketat pada identifikasi 18 faktor risiko utama stunting dan pengelompokkannya, yaitu nutrisi dan infeksi ibu; masa remaja dan interval kelahiran pendek; pembatasan pertumbuhan janin dan kelahiran prematur; gizi dan infeksi anak, serta faktor lingkungan. Seperti yang dijelaskan sebelumnya, risiko utama stunting di seluruh dunia adalah kelahiran prematur, yaitu kecilnya usia kehamilan, seperti dilahirkan pada usia kehamilan atau setelah 37 minggu kehamilan, tetapi terlalu kecil (Danaei et al., 2016).

Berbeda halnya di Uganda, para ibu yang kurang literasi mengenai cara menyusui kebanyakan tidak dapat memenuhi indikator-indikator yang harus dipenuhi dalam menyusui anaknya. Ibu dengan kemampuan literasi yang kurang akan mengalami krisis informasi mengenai bagaimana menyusui anak yang baik sehingga ada risiko kekurangan gizi bagi si anak. Faktor-faktor yang memengaruhi kualitas ibu menyusui harus lebih dipahami dalam konteks ini. Risiko kekurangan gizi dipengaruhi karena faktor praktik pemberian makanan bagi si anak. Sedangkan praktik pemberian makanan terkait dengan praktik pengasuhan (Ickes et al., 2015).

Hasil riset yang sudah dilakukan, dan upaya mentransformasikannya ke dalam kebijakan dan program, terutama untuk negara-negara berpenghasilan rendah maupun menengah, dirasa perlu (Mason et al., 2014). Penelitian tersebut output-nya bertujuan untuk melindungi, seperti nutrisi bayi dan meningkatkan angka kelahiran, dengan memperhatikan ibu sejak masa sebelum dan saat hamil. Dengan demikian dibutuhkan kebijakan-kebjakan di level kementerian maupun level donor. Keputusan maupun kebijakan tersebut harus dihasilkan berdasarkan bukti-bukti temuan yang ada di lapangan.

Data lapangan menunjukkan intervensi prioritas perlu dilakukan, seperti mengurangi kehamilan remaja dan meningkatkan jarak kehamilan melalui program keluarga berencana. Intervensi prioritas ini dipandang efektif, tetapi masih minim di dalam cakupan dan sumber daya yang belum memadai. Untuk 500 hari pertama bayi sepenuhnya bergantung pada nutrisi ibu. Praktik pengasuhan sang ibu di dalam fase ini sangat berperan besar, kecukupan nutrisi bergantung pada kematangan seorang ibu dalam mengurus sang anak, di antaranya terkait informasi kesehatan ibu dan anak (Mason et al., 2014).

Evidence-based practice yang ada di dunia, kiranya dapat direfleksikan di Indonesia, seperti pemberian nutrisi, sanitasi, dan juga program keluarga berencana. Selain itu, ibu perlu memiliki perencanaan matang, terutama mengatur interval kehamilan melalui program keluarga berencana demi mewujudkan pembangunan keluarga yang kokoh. Hal demikian tentu berpengaruh pada pola asuh anak, yang di dalamnya tentu terkait dengan bagaimana pemberian asi dan nutrisi anak. Tentu dalam mewujudkannya perlu melibatkan multi-sektor, yang sifatnya intervensi spesifik dan sensitif. 


\section{Intervensi Spesifik dan Sensitif Pencegahan Stunting}

Peran penguatan keluarga sebagai intervensi sensitif di dalam menekan angka stunting memiliki kedudukan penting. Dengan munculnya peningkatan kesadaran di masyarakat terhadap stunting dan pencegahannya dapat menciptakan kondisi lingkungan yang menopang program penguatan 1000 HPK dalam upaya mencegah stunting. Selain itu berdampak juga pada perubahan perilaku untuk terus menjaga rasa kesatuan dalam mencegah stunting dengan pembentukan kampung KB. Artinya menguatkan program pemerintah tentang kampung KB (Tentama et al., 2018).

Penelitian terkait (lih Tentama et al., 2018) memperlihatkan, misalnya, dalam konteks sosio-kultural masyarakat dengan aktivitas keseharian di bidang pertanian atau perkebunan menunjukkan peran orang tua yang begitu lemah, ditandai dengan seringnya orang tua meninggalkan anaknya di rumah ketika bekerja. Implikasinya adalah anak kurang mendapatkan asupan gizi, utamanya ASI dan MP-ASI. Dengan demikian, akan berpotensi terjadinya stunting, jika penguatan keluarga tidak diperkuat pada level masyarakat.

Hal lainnya, intervensi sensitif dan spesifik perlu ditekankan pada pemberian kursus persiapan perkawinan dengan muatan terkait kehidupan rumah tangga terutama masalah kesehatan dan gizi, sehingga kelak tidak melahirkan anak stunting. Beberapa program penurunan stunting yang inovatif, seperti BKB EMAS (Bina Keluarga Balita. Eliminasi Masalah Anak Stunting) dapat meningkatkan kesadaran, komitmen, praktik pengasuhan, dan kecukupan gizi ibu dan anak (Probohastuti dan Rengga, 2019).

Perlu disadari juga bahwa terdapat indikasi kuat anak yang lahir dari ibu dengan kondisi kekurangan pangan dan kesehatan yang buruk, tidak menyusui; berasal dari keluarga miskin, hidup tanpa fasilitas toilet (sanitasi buruk); tidak memiliki kemampuan literasi; interval kelahiran yang singkat, berhubungan dengan fenomena stunting pada anak. Untuk itu dibutuhkan pendidikan keluarga berencana serta kebijakan pendukungnya untuk menyelesaikan masalah stunting anak di bawah usia lima tahun (Takele, 2019).

Kekurangan nutrisi lebih banyak terjadi pada anak-anak dengan berat badan rendah dibandingkan dengan berat badan normal. Intervensi-intervensi yang lebih konkret yang sangat diperlukan. Selain itu perlu sinergi intervensi seperti menurunkan angka BBLR (Berat Badan Lahir Rendah). Asupan gizi yang diterima anak dari ibunya, berkelindan dengan pengetahuan ibu tentang nutrisi dan kaitannya dengan bayi lahir dengan berat badan rendah yang memperlihatkan malnutrisi di sana, dan ini memiliki determinan pada terjadinya stunting. Malnutrisi pada balita menjadi masalah yang signifikan dan terkait dengan interval kelahiran. Dengan demikian interval kelahiran yang lebih lama berasosiasi pada pengurangan prevalensi stunting (Rahman et al., 2016).

Keluarga berencana membantu pasangan untuk menghindari interval kelahiran anak yang terlalu pendek (stunting) (di bawah dua tahun) (Rana dan Goli, 2017). Pengaruh yang signifikan dari pernikahan dini yaitu pada gizi buruk pada anak. Pernikahan dini pada perempuan ditemukan tekait dengan peningkatan risiko kurang gizi anak. Selain itu, terdapat hubungan antara kekurangan gizi ibu dan anak dengan interval kelahiran pendek dan kehamilan berikutnya yang tidak diinginkan. Pernikahan dini menjadi elemen lain yang perlu mendapatkan perhatian.

Intervensi lintas sektor, dalam hal ini memasukkan program keluarga berencana sebagai strategi kunci dalam meningkatkan status gizi perempuan dan anak-anak. Sebab, layanan keluarga berencana yang modern dan efektif dapat secara signifikan mengurangi kurang gizi pada perempuan dan anak di negara-negara berkembang (Rana dan Goli, 2017), seperti Indonesia. Kongkretnya melalui program yang diimplementasikan oleh BKKBN dan Kementerian Kesehatan, sebagai upaya pemerintah kaitannya dengan intervensi sensitif pencegahan stunting, yaitu program Kependudukan, Keluarga Berencana, dan Pembangunan Keluarga (KKBPK) beserta intervensi spesifik yaitu peningkatan status gizi ibu dan anak. 


\section{Penurunan Prevalensi Stunting melalui Intervensi Sensitif Program Kependudukan, Keluarga Berencana, dan Pembangunan Keluarga (KKBPK) yang Terintegrasi}

Praktik keluarga berencana menjadi salah satu faktor penentu di dalam pencegahan stunting. Organisasi Kesehatan Dunia (WHO) telah menyerukan aksi global untuk mengurangi stunting hingga 40\% pada tahun 2025 (de Onis et al., 2013 dalam Saxton et al., 2016; Takele, 2019). Intervensi yang dapat dilakukan untuk mencegah stunting di antaranya meningkatkan akses ke dalam program keluarga berencana (Saxton et al., 2016).

Salah satu upaya pemerintah Indonesia untuk menurunkan prevalensi stunting yaitu dengan melibatkan lintas sektor, seperti yang sudah dibahas sebelumnya yaitu dengan Kementerian Kesehatan (intervensi spesifik) dan Badan Kependudukan dan Keluarga Berencana (BKKBN) dengan program unggulannya, yaitu program kependudukan, keluarga berencana, dan pembangunan keluarga (KKBPK), sebagai salah satu intervensi sensitif yang perlu dikuatkan.

BKKBN sebagai Lembaga Pemerintah non Kementerian diberikan mandat untuk mewujudkan agenda prioritas pembangunan, tepatnya Nawacita nomor 5, "Meningkatkan Kualitas Hidup Manusia Indonesia", yaitu dengan menyasar aspek pembangunan kependudukan dan keluarga berencana (Renstra BKKBN Tahun 2015-2019; KSP, 2019). Lebih lanjut dijelaskan berkaitan dengan kualitas penduduk, yang menjadi titik sentral di antaranya adalah terkait dengan status kesehatan.

Di dalam pembangunan berkelanjutan di Indonesia, yang harus menjadi titik sentral adalah penduduk. Seperti yang diamanatkan dalam Undang-undang Nomor 52 Tahun 2009, tentang Perkembangan Kependudukan dan Pembangunan Keluarga. Program KKBPK dapat diperkuat dengan memanfaatkan peluang bonus demografi yang akan dihadapi bangsa Indonesia (Renstra BKKBN Tahun 2015-2019; Mauluddin, 2019). Selain itu, fokus dari KKBPK yaitu memanfaatkan bonus demografi untuk meningkatkan kualitas penduduk. Notabene di tahun 2020 bangsa Indonesia didominasi oleh generasi milenial --rentang usia 20 hingga 40 tahun--, merupakan usia produktif yang dimiliki anak bangsa. Generasi Y, sebutannya, diproyeksikan berjumlah 83 juta jiwa (34\%) dari total penduduk Indonesia yang mencapai 271 juta jiwa. Proporsi anak muda harapan bangsa buah bonus demografi ini lebih besar dibandingkan generasi lainnya (seperti generasi X dan Z) (Mauluddin, 2019).

Selain itu, terdapat aspek penting lainnya di dalam pembangunan kependudukan, seperti mobilitas penduduk (urbanisasi). Hal demikian berpengaruh pada persebaran penduduk antarwilayah, dan berkaitan juga antara perkotaan dan perdesaan (Renstra BKKBN Tahun 20152019; Mauluddin, 2019). Senada dengan riset yang dilakukan Mauluddin (2019) bahwa terdapat kaitannya urbanisasi dan kependudukan. Pada tahun 2050, diprediksi sekitar $70 \%$ penduduk dunia akan tinggal di perkotaan (FES, 2017, dalam Mauluddin dan Lestari, 2019; Venerandi et al., 2018). Tahun 2018 saja, sudah sekitar 54\% (Venerandi et al., 2018). Tren peningkatan ini tidak terlepas dari faktor urbanisasi yang sejak satu dekade terakhir kecenderungannya sudah terlihat. Misalnya, di tahun 1950 hanya 30\% penduduk dunia yang tinggal di perkotaan (Venerandi e al., 2018). Kasus Indonesia, misalnya, data BPS (2010) mencatat proporsi penduduk yang tinggal di perkotaan di tahun tersebut sebesar 49,8 persen, dan tahun 2018 sudah sekitar 55 persen (Kompas, 2018; Mauluddin dan Lestari, 2019). Bonus demografi dan urbanisasi kiranya perlu direspons secara tepat dengan berfokus kepada target-target yang ingin dicapai pemerintah, terutama melalui Nawacitanya. Seperti termaktub dalam Renstra BKKBN Tahun 2015-2019 bahwa diperlukan komitmen bersama dan meningkatkan kerjasama lintas sektor dalam upaya mencapai target/sasaran yang telah ditetapkan dalam Renstra. Muaranya pada tercapainya agenda prioritas pembangunan No. 5 (Nawacita) yaitu meningkatkan kualitas hidup manusia Indonesia.

Seperti tercantum di dalam RPJMN 2015 - 2019 Buku II, Bab II - Bidang Sosial budaya (Renstra BKKBN Tahun 2015-2019) masih terdapat beberapa permasalahan di antaranya komitmen dan dukungan stakeholder yang masih lemah terhadap program KKBPK. Khususnya terkait kelembagaan, kebijakan, perencanaan, dan penganggaran program. Seperti disebutkan juga dalam artikelnya Muchlis dan Marom (2018) yang memberikan rekomendasi bahwa 
pentingnya komitmen pemerintah dalam penyelenggaraan program KKBPK agar terlaksana secara optimal.

Komitmen pemerintah dalam penanggulangan stunting penting, karena hak asasi anak untuk mendapatkan kesehatan merupakan HAM bagi anak. Dengan demikian mengabaikan hak anak merupakan pelanggaran HAM. Hal ini menjadi tanggung jawab bersama. Pengurangan prevalensi stunting pun perlu dilakukan secara holistik dengan melibatkan berbagai sektor yang memiliki komitmen bersama menanggulangi stunting, utamanya negara, orang tua, keluarga, dan masyarakat (Haryanti dan Nurhayati, 2019; Tempo, 2019).

Program KKBPK perlu ditinjau dari berbagai temuan-temuan riset terkait yang sudah dipublikasikan para peneliti di dunia, beberapa di antaranya penelitian Rostein (2005) mengungkapkan bahwa jarak kelahiran kurang dari 36 bulan meningkatkan risiko kematian maupun kekurangan nutrisi pada anak. Artikel tersebut merekomendasikan bahwa interval kelahiran yang baik dan optimal adalah di kisaran 36 hingga 59 bulan. Senada dengan hasil penelitiannya Saxton et al., (2016) yang menemukan bahwa interval kelahiran lebih dari 24 bulan. Walaupun tidak secara tegas disebutkan berapa interval tepatnya, tetapi dapat ditarik kesimpulan interval kelahiran berpotensi mencegah stunting maksimal 24 bulan atau jarak 2 tahun. Argumen dari riset Saxton et al., (2016) tersebut lebih kepada praktik keluarga berencana yang merupakan faktor penentu utama dan paling kuat di dalam mencegah stunting. Seperti telah dikerjakan WHO, dengan menyerukan aksi global untuk mengurangi stunting hingga 40\% di tahun 2025 (de Onis et al., 2013 dalam Saxton et al., 2016; Takele, 2019). Intervensi yang dapat dilakukan untuk mencegah stunting di antaranya meningkatkan akses ke program KB. Selain itu, salah satu temuan yang menarik dari risetnya Saxton et al., (2016) yaitu jarak kelahiran yang memadai dan intervensi meminimalkan kehamilan yang tidak diinginkan dapat mengurangi prevalensi stunting. Diperkuat oleh penelitiannya Takele (2019) bahwa jarak kelahiran pendek berkaitan dengan masalah stunting. Temuan ini penting, karena ditemukan bahwa anak-anak dalam waktu kurang dari 24 bulan dari interval kelahiran sebelumnya berisiko tinggi mengalami stunting.

Stunting menjadi indikator dari hasil malnutrisi (Takele, 2019). Seperti diketahui bahwa akibat yang ditimbulkan dari stunting yaitu kerusakan fisik (masalah kesehatan) dan kognitif yang tidak dapat diperbaiki, tetapi dapat dicegah. Pencegahan dapat dilakukan melalui identifikasi faktor risiko sejak dini. Data global menunjukkan kematian anak menurun, tetapi anak-anak di seluruh dunia masih mengalami keterlambatan pertumbuhan fisik (stunting). Faktanya, 30\% anak-anak di negara berkembang mengalami keterlambatan pertumbuhan. Misalnya anak-anak memiliki ketinggian lebih dari dua standar deviasi di bawah tinggi rata-rata stadar global untuk usia mereka (Danaei et al., 2016).

Temuan menarik lainnya, 1000 HPK merupakan periode terpenting, karena perkembangan di masa ini berdampak pada seorang anak selama sisa hidupnya. Kemudian, dijelaskan bahwa stunting selama periode ini menentukan hasil buruk terkait kesehatan, perkembangan kognitif, dan pencapaian pendidikan dan ekonomi di kemudian hari.

Jumlah anak yang menderita kekurangan nutrisi di Asia Tenggara sama dengan jumlah di Sub-Sahara Afrika. Perencanaan kelahiran menjadi salah satu hal penting yang memengaruhi kurangnya nutrisi anak tersebut. Penelitian tersebut menemukan bahwa selain mengendalikan aspek sosial dan ekonomi, anak yang lahir lebih dari 24 bulan pasca pernikahan memiliki kerentanan lebih rendah terhadap stunting. Perencanaan kelahiran anak dengan jarak 24 bulan dengan metode demografis dapat menurunkan angka stunting di negara-negara berkembang seperti Asia Tenggara (Rana dan Goli, 2018).

Penelitian Rana et al., (2019) mengungkapkan fakta bahwa perempuan dengan jarak kelahiran kurang dari dua tahun lebih berisiko memiliki anak yang menderita kekurangan berat badan. Kekurangan berat badan dapat mengarah ke penyakit seperti stunting, atau gizi buruk, anemia bahkan kematian. Perempuan dengan jarak kelahiran lebih dari tiga tahun akan semakin jauh dengan risiko tersebut. Temuan dari riset juga menjelaskan pentingnya perencanaan kelahiran dalam meningkatkan hasil kesehatan ibu, anak, dan gizi anak.

Penelitian Sobrino et al., (2017) mengungkapkan penurunan stunting di Peru pada tahun 1996-2014. Pada interval kelahiran 24 bulan atau kurang, persentase stunting menurun dari sebelumnya $35,8 \%$ menjadi $21,8 \%$, pada interval kelahiran lebih dari 24 bulan, stunting juga 
menurun dari 29,5\% menjadi 14,3\%. Penelitian tersebut menyimpulkan bahwa interval kelahiran minimal dua tahun atau 24 bulan merupakan hal krusial yang menjadi penyebab menurunnya risiko stunting. Kemiskinan, rendahnya pendidikan ibu dan banyaknya anak dalam keluarga memiliki hubungan yang erat dengan fenomena stunting pada tahun-tahun tersebut (Sobrino et al., 2017). Temuan menarik lainnya yaitu interval kelahiran lebih dari 24 bulan memberikan efek perlindungn terhadap terjadinya stunting.

Penelitian-penelitian yang dipaparkan memperkuat bahwa dalam konteks Indonesia, bentuk kongkret dari temuan-temuan riset yang menitikberatkan pada pembangunan keluarga dan interval kelahiran dapat terimplementasi melalui program Kependudukan, Keluarga Berencana, dan Pembangunan Keluarga (KKBPK).

\section{KESIMPULAN}

Program Kependudukan, Keluarga Berencana, dan Pembangunan Keluarga (KKBPK) dapat terimplementasi secara optimal jika terdapat komitmen di level pimpinan untuk pencegahan stunting di 1000 HPK. Komitmen pimpinan dari pusat hingga daerah diperlukan, karena hak anak untuk mendapatkan kesehatan (tidak stunting) menjadi hak asasi manusia (HAM Anak) yang dilindungi oleh negara. Upaya pemerintah yang melibatkan multi-sektor tidak hanya Kementerian Kesehatan tetapi dengan Badan Kependudukan dan Keluarga Berencana Nasional (BKKBN) di dalam pencegahan stunting merupakan langkah yang tepat. Penguatan di program KKBPK terkait dengan kampanye pengaturan interval kelahiran minimal 24 bulan (anak pertama dengan kelahiran berikutnya), perlu digencarkan sebagai kampanye pencegahan stunting. Kampenye ini dapat diperkuat dengan dijadikannya sebagai gerakan nasional pencegahan stunting yang melibatkan lintas sektor dan komitmen pimpinan atau stakeholder di institusi terkait.

\section{DAFTAR PUSATAKA}

Batiro, B., Demissie, T., Halala, Y., \& Anjulo, A. A. (2017). Determinants of stunting among children aged 6-59 months at Kindo Didaye woreda, Wolaita Zone, Southern Ethiopia: Unmatched case control study. PLoS ONE, 12(12). https://doi.org/10.1371/journal.pone.0189106

BKKBN. (2018). "Laporan 4 Tahun Pemerintahan Joko Widodo - Jusuf Kalla." https://www.bkkbn.go.id/po-content/uploads/Laporan-4-Tahun-Jokowi-JK.pdf, diakses 23 Desember 2019.

Danaei, G., Andrews, K. G., Sudfeld, C. R., Fink, G., McCoy, D. C., Peet, E., ... Fawzi, W. W. (2016). Risk Factors for Childhood Stunting in 137 Developing Countries: A Comparative Risk Assessment Analysis at Global, Regional, and Country Levels. PLoS Medicine, 13(11). https://doi.org/10.1371/journal.pmed.1002164

Data BPS tahun 2010.

Haryanti, T., \& Hayati, N. (2019). Penegakan Hukum Hak Asasi Manusia bagi Anak Penderita Stunting. Jurnal HAM, 10(2), 249. https://doi.org/10.30641/ham.2019.10.249-260

Ickes, S. B., Hurst, T. E., \& Flax, V. L. (2015). Maternal literacy, facility birth, and education are positively associated with better infant and young child feeding practices and nutritional status among Ugandan children.Journal of Nutrition,145(11), 2578-2586. https://doi.org/10.3945/jn.115.214346

Kementerian Kesehatan RI. (2017). Pemantauan Status Gizi. Buku Saku Pemantauan Status Gizi Tahun 2017, 7-11.

Koran Kompas, 2018, diakses per Desember 2018.

KSP. (2019). Lima Tahun Maju Bersama. Capaian Pemerintahan Joko Widodo - Jusuf Kalla. Kantor Staf Presiden Republik Indonesia Gedung Bina Graha Jl Veteran No. 16 Jakarta.

Mauluddin, A. (2019). Urban Millennial: Analisis Kebijakan Tata Ruang Kota untuk "Gen- $Y$ " di Indonesia. CIC Lembaga Riset dan Konsultan Sosial (Vol. 1, pp. 17-32). Retrieved from http://journal.cicofficial.com/index.php/jbo/article/view/2

Mauluddin, A dan Lestari, S. (2019). Kota Cerdas dan Kebijakan Pendidikan dalam Perspektif Sosiologi. JISPO VOL. 9 No. 2 Edisi: Juli-Desember Tahun 2019. 
Mason, J. B., Shrimpton, R., Saldanha, L. S., Ramakrishnan, U., Victora, C. G., Girard, A. W. ebb, ... Martorell, R. (2014). The first 500 days of life: policies to support maternal nutrition. Global Health Action. https://doi.org/10.3402/gha.v7.23623

Muchlis, S., \& Marom, A. (2018). EVALUASI PROGRAM KEPENDUDUKAN KELUARGA BERENCANA DAN PEMBANGUNAN KELUARGA (KKBPK) DALAM MENEKAN ANGKA KEMATIAN IBU DI KOTA SEMARANG Suryanto. Journal of Public Policy and Management Review, 7(2), 23-35.

Pusat Data dan Informasi Kemenkes RI. (2018). Buletin Jendela Data dan Informasi Kesehatan: Situasi Balita Pendek di Indonesia.Kementerian Kesehatan RI, 56. Retrieved from www.pusdatin.kemkes.go.id

Probohastuti, N. F., Rengga, D. A., \& Si, M. (2017). Implementasi Kebijakan Intervensi Gizi Sensitif Penurunan Stunting di Kabupaten Blora. Jurnal Administrasi Publik FISIP UNDIP, 1-16.

Rahman, M. S., Howlader, T., Masud, M. S., \& Rahman, M. L. (2016). Association of low-birth weight with malnutrition in children under five years in Bangladesh: Do mother's education, socio-economic status, and birth interval matter? PLOS ONE, 11(6). https://doi.org/10.1371/journal.pone.0157814

Rana, M. J., Gautam, A., Goli, S., Uttamacharya, Reja, T., Nanda, P., ... Verma, R. (2019). Planning of births and maternal, child health, and nutritional outcomes: recent evidence from India. Public Health, 169, 14-25. https://doi.org/10.1016/j.puhe.2018.11.019

Rana, M. J., \& Goli, S. (2018). Does planning of births affect childhood undernutrition? Evidence from demographic and health surveys of selected South Asian countries. Nutrition, 47, 9096. https://doi.org/10.1016/j.nut.2017.10.006

. (2017). The returns of family planning: Macro-level assessment of the effect of contraceptive use on women's anaemia and childhood undernutrition. Journal of Biosocial Science, 49(6), 773-791. https://doi.org/10.1017/S0021932016000717

BKKBN. (2015). Rencana Strategis Badan Kependudukan Dan Keluarga Berencana Nasional Tahun 2015-2019. Badan Kependudukan Dan Keluarga Berencana Nasional, 1(1), 1-43.

Kementerian Kesehatan RI Badan Penelitian dan Pengembangan. (2018). Hasil Utama Riset Kesehatan Dasar. Retrieved from http://www.depkes.go.id/resources/download/infoterkini/hasil-riskesdas-2018.pdf

Rutstein, S. 0. (2005). Effects of preceding birth intervals on neonatal, infant and under-five years mortality and nutritional status in developing countries: Evidence from the demographic and health surveys. International Journal of Gynecology and Obstetrics, 89(SUPPL. 1). https://doi.org/10.1016/j.ijgo.2004.11.012

Saxton, J., Rath, S., Nair, N., Gope, R., Mahapatra, R., Tripathy, P., \& Prost, A. (2016). Handwashing, sanitation and family planning practices are the strongest underlying determinants of child stunting in rural indigenous communities of Jharkhand and Odisha, Eastern India: a crosssectional study.Maternal and Child Nutrition, 12(4), 869-884. https://doi.org/10.1111/mcn.12323

Sobrino, M., Gutiérrez, C., Alarcón, J., Dávila, M., \& Cunha, A. J. (2017). Birth interval and stunting in children under five years of age in Peru (1996-2014). Child: Care, Health and Development, 43(1), 97-103. https://doi.org/10.1111/cch.12420

Takele, K., Zewotir, T., \& Ndanguza, D. (2019). Understanding correlates of child stunting in Ethiopia using generalized linear mixed models. BMC Public Health, 19(1). https://doi.org/10.1186/s12889-019-6984-x

Tentama, F., Delfores, H. D. L., Wicaksono, A. E., \& Fatonah, S. F. (2018). PENGUATAN KELUARGA SEBAGAI UPAYA MENEKAN ANGKA STUNTING DALAM PROGRAM KEPENDUDUKAN, KELUARGA BERENCANA DAN PEMBANGUNAN KELUARGA (KKBPK). Jurnal Pemberdayaan: Publikasi Hasil Pengabdian Kepada 113. https://doi.org/10.12928/jp.v2i1.546

Tempo. (2019). Air Susu Ibu sebagai Hak Asasi. Opini Koran Tempo Irma Hidayana, edisi, 10 Desember 2019.

Thousanddaysorg. (2019). Diakses pada 10 Desember 2019. 
UNICEF/WHO/World Bank Group. (2018). Levels and trensds in child malnutrition 2018. Joint Child Malnutrition Estimates 2018 Edition, 1-15. Retrieved from http://www.who.int/nutgrowthdb/estimates2017/en/

Venerandi, A., Quattrone, G., \& Capra, L. (2018). A scalable method to quantify the relationship between urban form and socio-economic indexes. EPJ Data Science,7(1). https://doi.org/10.1140/epjds/s13688-018-0132-1 